\title{
IMPLEMENTASI PENDEKATAN SAINTIFIK PADA PEMBELAJARAN DARING SELAMA MASA PANDEMI COVID- 19 DI LEMBAGA PENDIDIKAN DASAR
}

\author{
Ahmad Izzuddin \\ STIT Palapa Nusantara Lombok NTB \\ ahmadizzuddinmsi@gmail.com
}

\begin{abstract}
The impact of the Covid-19 pandemic is felt at all levels of education, from elementary to bigher education. The existence of this pandemic has become a challenge for educators to innovate in developing and implementing lesson plans that have been prepared previously. One of the learning approaches used is the scientific approach. This approach trains students to learn with the scientific method through the process of observing, asking questions, gathering information, experimenting, associating and communicating the material they are learning. This is where the ability of a teacher is required to be creative in integrating the steps of the scientific approach with online methods. During the past year, the implementation of a scientific approach in online learning during the Covid-19 pandemic has been carried out in basic education institutions with quite good results. Some of the advantages of the scientific approach using online learning include (1) the dependence of students on educators is slightly reduced because learning is carried out more at home through the network. (online) (2) the flexibility of time and place to take the steps of the scientific approach to be a separate experience for students (3) train students to use learning technology from an early age. The weaknesses of online learning include (1) internet signal/ connection is not very stable (2) teacher and student interactions cannot interact directly (3) still lack of facilities and infrastructure in the implementation of online learning (4) inadequate parental supervision This causes students to often lose focus in learning.
\end{abstract}

Keywords: Scientific Approach, Online Learning, Covid-19 Pandemic

\begin{abstract}
Abstrak : Dampak Pendemi covid-19 dirasakan di semua jenjang Pendidikan mulai dari jenjang Pendidikan Dasar sampai Perguruan tinggi. Adanya pandemi ini, menjadi tantangan tersendiri bagi pendidik untuk berinovasi mengembangkan dan melaksanakan perencanaan pembelajaran yang telah disiapkan sebelumnya. Salah satu pendekatan pembelajaran yang digunakan adalah pendekatan saintifik. Pendekatan ini melatih siswa untuk belajar dengan metode ilmiah melalui proses mengamati, menanya, mengumpulkan informasi, mencoba, mengasosiasi serta mengkomunikasikan materi yang dipelajarinya. Disinilah kemampuan seorang guru dituntut untuk kreatif mengintegrasikan langkah pendekatan saintifik tersebut dengan metode daring.
\end{abstract}

AS-SABIQUN : Jurnal Pendidikan Islam Anak Usia Dini

Volume 3, Nomor 1, Maret 2021; 45-63

https://ejournal.stitpn.ac.id/index.php/assabiqun 
Selama satu tahun terakhir implementasi pendekatan saintifik dalam pembelajaran daring pada masa pandemi covid-19 sudah dilaksanakan di lembaga pendidikan dasar dengan hasil yang cukup baik. Beberapa kelebihan pendekatan saintifik menggunakan pembelajaran daring antara lain (1) ketergantungan siswa terhadap pendidik sedikit berkurang karena pembelajaran dilakukan lebih banyak di rumah melalui jaringan (online) (2) fleksibilitas waktu dan tempat melakukan langkah-langkah pendekatan saintifik menjadi pengalaman tersendiri bagi siswa (3) melatih siswa menggunakan teknologi pembelajaran sejak usia dini. Adapun kelemahan pembelajaran daring ini antara lain (1) sinyal/koneksi internet belum terlalu stabil (2) interaksi guru dan siswa tidak dapat berintraksi secara langsung (3) masih kurangnya sarana dan prasarana dalam pelaksanaan pembelajaran daring (4) pengawasan orang tua yang masih kurang mengakibatkan siswa sering kehilangan focus dalam pembelajaran.

Kata Kunci : Pendekatan Saintifik, Pembelajaran Daring, Pandemi Covid-19

\section{PENDAHULUAN}

Dunia pendidikan saat ini sedang dihadapkan dengan tantangan yang berat dan rumit dengan masuknya virus corona di Indonesia. Dampak yang diakibatkan oleh virus ini sangat besar. Hal itu dapat dilihat dan dirasakan pada kehidupan masyarakat, mulai dari kesehatan, ekonomi, sosial, keagamaan maupun pendidikan. Semua komponen mulai dari pemerintah, satuan pendidikan, guru, siswa dan orang tua berusaha maksimal untuk beradaptasi dengan perubahan signifikan yang diakibatkan wabah yang sudah menjadi pandemic ini.

Dampak virus corana dalam dunia pendidikan bisa terlihat pada kebijakan yang dikeluarkan oleh pemerintah. Pemerintah pusat dan pemerintah daerah berupaya mensingkronkan kebijakan yang dapat dilakukan oleh masyarakat. Salah satu kebijakan yang diterapkan adalah meliburkan seluruh lembaga pendidikan dari tingkat Pendidikan Anak Usia Dini (PAUD) sampai perguruan tinggi. Hal ini ditempuh oleh pemerintah sebagai upaya mencegah meluasnya penularan virus corona. Semua lembaga pendidikan diharuskan untuk tidak melaksanakan aktivitas tatap muka, guna meminimalisir penyebaran penyakit covid-19 ini. Pendidik sebagai ujung tombak proses pembelajaran dituntut untuk lebih kreatif mengelola pembelajaran secara online, sehingga proses 
pembelajaran tetap berlangsung. Tuntutan ini berlaku untuk semua jenjang Pendidikan mulai tingkat Pendidikan Anak Usia Dini (PAUD) sampai perguruan tinggi. Pendidik di Sekolah Dasar/Madrasah Ibtidaiyah juga harus dituntut lebih kreatif dalam mengelola pembelajaran secara online. Pendidik Sekolah Dasar/Madrasah Ibtidaiyah harus memiliki keahlian dalam melakukan refleksi dan menganalisis kegiatan mengajarnya. Karakteristik ini perlu dikembangkan untuk meningkatkan kemampuan guru dalam mengembangkan rencana lanjutan ${ }^{1}$.

Metode maupun pendekatan pembelajaran harus disesuaikan dengan keadaan yang sedang terjadi. Dengan penyesuaian tersebut maka proses pembelajaran dapat tetap berjalan sehingga indikator pencapaian perkembangan anak bisa dipertanggungjawabkan kepada orang tua. Kegiatan pelaksanaan pembelajaran yang meliputi pembukaan, kegiatan inti dan penutup sebagaimana tertuang dalam standar yang telah ditentukan juga harus tetap dipertahankan ${ }^{2}$. Hasil analisis selama pembelajaran online disampaikan pada orang tua dilakukan secara periodik. Hal ini dilakukan untuk mengetahui sejauh mana kekuatan dan kelemaahan rencana dan pelaksanaan pembelajaran. Usaha perbaikan harus terus dilakukan pendidik untuk memperbaiki perencanaan dan pelaksanaan pembelajaran supaya menghasilkan kualitas pembelajaran online yang lebih baik. Belum usainya masa tanggap darurat pandemi Covid-19, menjadi tantangan tersendiri bagi masyarakat untuk semakin meningkatkan kesadaran menjaga kesehatan dan lingkungan setiap saat. Tidak terkecuali pendidik pada jenjang Sekolah Dasar/Madrasah Ibtidaiyah yang harus lebih keras mempersiapkan segala sesuatu untuk kebutuhan pembelajaran online.

Pendidik harus berusaha agar kegiatan belajar mengajar tetap berjalan, meskipun peserta didik berada di rumah. Pendidik dituntut kreatif dalam mendesain media pembelajaran sebagai salah satu inovasi yang dapat mengembangkan kualitas pembelajaran, salah satunya adalah dengan memanfaatkan media daring (online). Hal ini sesuai dengan edaran yang telah dikeluarkan pemerintah pusat melalui Menteri Pendidikan dan Kebudayaan Republik Indonesia. Surat edaran mendikbud Nomor 4 Tahun 2020 tentang Pelaksanaan Kebijakan Pendidikan dalam Masa Darurat

1 Anhusadar L. O. "Kualifikasi Pendidik Sesuai Permendikbud Nomor 137”, Journal On Early Childhood Education Resears Joecher, 2020, hlm 55

2 Suryosubroto, B. 2009. Proses Belajar Mengajar di Sekolah. Rineka Cipta. Jakarta. 
Penyebaran Corona Virus Disease (Covid-19) ${ }^{3}$ menjadi payung hukum sebagai acuan pendidik untuk dapat melakukan pembelajaran daring.

Proses pembelajaran daring yang diterapkan hendaknya sesuai dengan ketentuan kurikulum 2013 yakni penerapan pendekatan saintifik. Pendekatan saintifik dilakukan melalui lima langkah pembelajaran yaitu mengamati, menanya, mencoba, menalar dan mengkomunikasikan. Kelima langkah tersebut diharapkan dapat dimunculkan secara menyeluruh dalam proses pembelajaran. Hal itu bertujuan agar peserta didik dapat menunjukkan kinerja yang positif dan aktif dalam mengikuti pembelajaran yang diberikan. Hal ini selaras dengan tujuan pendidikan yang digunakan pada kurikulum 2013 yaitu menciptakan pengajaran yang dapat berpusat pada peserta didik ${ }^{4}$. Akan tetapi untuk memunculkan kelima langkah tersebut dalam satu pertemuan cukup sulit karena dilakukan secara daring.

Pada satuan pendidikan dasar pelaksanaan pembelajaran daring masih terbilang jarang atau bahkan belum pernah dilaksanakan selama ini. Sehingga penerapan pembelajaran daring di lembaga pendidikan dasar akan banyak menghadapi berbagai kendala. Perubahan kebiasaan yang terjadi pada diri siswa, menjadi salah satu hal yang paling dapat diamati, awalnya diterima dengan baik, antusias karena kegiatan akan dilakukan di rumah, namun seiring berjalannya waktu akan menimbulkan kejenuhan dalam diri siswa. Kejenuhan itu muncul manakala siswa melakukan sebuah rutinitas yang sama setiap hari. Selain itu, intensitas guru dalam menyampaikan materi menjadi berkurang sehingga hasil yang diperoleh pun kurang maksimal. Dengan demikian perkembangan belajar anak akan sangat bergantung pada baik tidaknya proses kegiatan belajar mengajar yang disampaikan guru. Perkembangan belajar anak di rumah pada masa pandemi covid-19 ini akan cenderung berbeda dengan perkembangan belajar di sekolah sehingga guru sebagai fasilitator harus memiliki berbagai inovasi serta memberikan motivasi bagi siswa dalam melaksanakan kegiatan belajar mengajar. ${ }^{5}$

${ }^{3}$ L. G. M. Z. Atsani, Transformasi Media Pembelajaran Pada Masa Pandemic Covid-19. Al-Hikmah: Jurnal Studi Islam, 2020, hlm 44-45.

4 Musfiqon \& Nurdyansyah. (2015). Pendekatan Pembelajaran saintifik. Sidoarjo: Nizamia Learning Center.

${ }^{5}$ Depdiknas, Permendiknas N0 22 Tahun 2006 Tentang Standar Isi (Jakarta: Depdiknas, 2006) 
Berdasarkan hasil observasi di lembaga pendidikan dasar/madrasah ibtidaiyah bahwa pembelajaran sekarang dilaksanakan secara daring melalui grup whatsapp. Proses pembelajaran daring dilaksanakan menggunakan media pembelajaran yang memerlukan perangkat yang dapat terhubung dengan jaringan internet. Salah satu media yang digunakan adalah handphone dengan memanfaatkan aplikasi whatsapp. Proses pembelajaran yang dilaksanakan seharusnya sesuai dengan pembelajaran yang terdapat didalam kurikulum yang menerapkan pendekatan saintifik. Akan tetapi, proses pembelajaran masih belum dilaksanakan mengikuti langkah-langkah pada pendekatan saintifik. Hasil survei yang dirilis oleh KPAI pada bulan april 2020 membuktikan bahwa terdapat $77,6 \%$ guru membuat persiapan pembelajaran online hanya dalam bentuk penugasan. Artinya pembelajaran daring tidak berorientasi pada proses penerapan pendekatan saintifik. Pembelajaran daring seharusnya dilaksanakan oleh guru sehingga interaksi guru dalam proses pembelajaran daring tidak berjalan dengan efektif ${ }^{6}$.

Penggunaan WhatsApp Group pada kegiatan belajar dari rumah merupakan pembelajaran yang mudah dan fleksibel. Aplikasi ini dipilih sebagai media penghubung antara guru, anak, dan orang tua karena didukung oleh sarana dan prasarana yang cukup memadai. Dimasa pandemi ini, WhatsApp Group dapat digunakan sebagai salah satu alternatif media pembelajaran meskipun kondisi berbatas jarak, ruang dan waktu. Fitur yang ada juga sudah umum di masyarakat, seperti fitur pesan teks, pesan suara, panggilan video, menerima dan mengirim gambar, video dan dokumen file.

Penggunaan Whatsapp Group memudahkah guru, siswa maupun orang tua dalam proses kegiatan yang telah direncanakan. Penggunaan aplikasi ini akan menghindari pengumpuln massa di sekolah karena tugas maupun materi pelajaran akan dikirim melalui aplikasi Whatsapp Group disertai dengan penjelasan singkat dalam melakukan Langkah-langkah pembelajaran. Data yang telah diperoleh dari hasil laporan kegiatan baik yang diperoleh dari grup Whatsapp Group dianalisis sesuai dengan kompetensi dasar dan aspek perkembangan anak dianalisis dan dibuatkan suatu laporan. Laporan perkembangan anak dapat dilakukan secara tatap muka langsung dengan tetap

${ }^{6}$ Pohan, A. E. (2020). Konsep Pembelajaran Daring Berbasis Pendekatan Ilmiah. Jawa Tengah: Sarnu Untung.

${ }^{7}$ Nugraheni, A. S, Dan Hutami, M. S. "Metode Pembelajaran Melalui Whatsapp Group Sebagai Antisipasi Penyebaran Covid-19 Pada AUD, Paudia: Jurnal Penelitian Dalam Bidang Pendidikan Anak Usia Dini, 2020, Hlm 126-140. 
memperhatikan protokol kesehatan agar lebih dalam mengetahui perkembangan anak dan efektivitas pembelajaran online di tengah Pandemi Covid-19 $9^{8}$.

\section{Pemdekatan Saintifik}

Pembelajaran dengan menggunakan pendekatan saintifik menekankan pada pemberian pengalaman secara langsung kepada anak. Pengalaman langsung tersebut bisa menggunakan observasi, percobaan sederhana maupun cara lain yang sesuai dengan langkah-langkah pendekatan saintifik. Penekanan tersebut bertujuan agar informasi atau data yang diperoleh valid dan dapat dipertanggungjawabkan?. Pendekatan scientifik adalah pembelajaran yang menggunakan kaidah-kaidah keilmuan. Pendekatan scientifik atau metode ilmiah pada umumnya memuat serangkaian aktifitas, pengumpulan data melalui observasi, menanya, eksperimen, mengolah informasi atau data, kemudian mengkomunikasikan.

Pendekatan saintifik adalah pendekatan untuk membangun bentuk sikap yang religi, sosial, pengetahuan dan keterampilan pada siswa. Pendekatan saintifik dapat memberikan suatu pemahaman kepada siswa dalam mengenal suatu informasi dan memahami berbagai materi yang menggunakan pendekatan ilmiah. Informasi tersebut dapat berasal dari berbagai sumber dan tidak bergantung pada informasi yang diberikan oleh dari guru ${ }^{10}$. Penerapan pendekatan saintifik dalam pembelajaran melibatkan suatu keterampilan yang terdapat pada suatu proses. seperti mengamati, menanya, mencoba, menalar, dan mengkomunikasikan ${ }^{11}$.

Metode saintifik memiliki langkah-langkah sebagai berikut mengidentifikasi masalah (dari fakta yang ditemukan di lingkungan), mengumpulkan data yang sesuai dengan permasalahan yang ditemukan, memilah data yang sesuai dengan permasalahan, merumuskan hipotesis (dugaan ilmiah yang menjelaskan data dan permasalahan yang

\footnotetext{
${ }^{8}$ B. Basori, Efektifitas Komunikasi Pembelajaran Online Dengan Menggunakan Media E-Learning Pada Perkuliahan Body Otomotif. Jurnal Ilmiah Pendidikan Teknik Dan Kejuruan, 2017, Hlm 39-45.

${ }^{9}$ Agus Sujarwanta. (2012). "Mengkondisikan Pembelajaran IPA dengan Pendekatan Saintifik". Jurnal Nuansa Kependidikan Vol 16 Nomor.1, November 2012.

${ }^{10}$ Majid. (2014). Penggunaan Pendekatan Pembelajaran Saintifik dalam Menggunakan Hasil

Belajar Matematika. Jurnal Ilmiah Mandala education

${ }^{11}$ Hosnan \& Sihombang. (2014). Pengaruh Pendekatan Pembeljaran Matematika Realistik dan Saintifik terhadap Prestasi Belajar, Kemampuan Penalaran Matematis dan Minat Belajar. Jurnal Riset Pendidikan Matematika
} 
ada sehingga dapat menentukan langkah penyelesaian masalah lebih lanjut), menguji hipotesis dengan mencari data yang lebih faktual (mengadakan eksperimen), menguji keakuratan hipotesis yang telah dirumuskan sebelumnya agar dapat mentukan tindakan terhadap hipotesis tersebut (mengkonfirmasi, memodifikasi, ataupun menolak hipotesis).

Adapun langkah kegiatan, kegiatan belajar, dan aspek yang dikembangkan dalam pendekatan saintifik.

a. Mengamati (observing)

Dalam kegiatan mengamati siswa tidak hanya dituntut untuk sekedar melihat saja akan tetapi siswa diajak untuk melihat, mendengar, menyimak, dan membaca suatu materi yang diberikan oleh guru agar siswa mampu menemukan fakta yang ada hubungannya dengan materi ${ }^{12}$. Kemampuan ini akan memberikan pengalaman yang sangat baik pada siswa karena mereka akan memahami materi dengan sepunuh hati. Kegiatan menyimak disertai dengan kemampuan membaca dan mendengar akan membiasakan siswa untuk selalu berpikir sebelum melakukan sesuatu.

Keterampilan mengamati merupakan keterampilan dasar yang harus dimiliki. Proses mengamati dapat dilakukan dengan menggunakan panca indera, tetapi tidak menutup kemungkinan pengamatan dilakukan dengan menggunakan alat-alat, misalnya termometer, timbangan, atau mikroskop ${ }^{13}$.

b. Menanya (Questioning)

Menanya dalam kegiatan pembelajaran menggunakan pendekatan saintifik adalah mengajukan pertanyaan tentang informasi yang tidak dipahami dari apa yang diamati. Kegiatan menaya ini bisa langsung dilakukan secara spontan atau siswa diarahkan untuk mendapatkan sebuah pertanyaan dari materi yang sedang dibahas. Menanya dapat mengembangkan berbagai kompetensi dalam diri siswa antara lain mengembangkan kreativitas, rasa ingin tahu, kemampuan merumuskan pertanyaan

12 Abdul Majid. (2014). Pembelajaran Tematik Terpadu. Bandung: PT Remaja RoMIakarya

13 Usman Samatowa. (2011). Bagaimana Membelajarkan IP A. Jakarta: Dirjen Dikti Depdiknas. 
untuk membangun serta membetuk siswa yang mempu berpikir kritis ${ }^{14}$ sehingga dapat diterapkan dalam kehidupan sehari-hari.

c. Mengumpulkan Informasi/ Eksperimen

Tindak lanjut dari kegiatan menanya adalah mengumpulkan informasi. Kegiatan ini dilakukan dengan menggali dan mengumpulkan informasi dari berbagai sumber melalui beragam cara. Peserta didik dapat membaca berbagai sumber belajar seperti buku, brousing internet, memperhatikan fenomena, objek dengan teliti, atau bahkan melakukan percobaan/eksperimen. Aktivitas pengumpulan informasi diatur juga dalam Peraturan Menteri Pendidikan dan Kebudayaan Nomor 81a Tahun 2013. Dalam peraturan tersebut pengumpulan informasi dilakukan melalui eksperimen, membaca sumber lain selain buku teks, mengamati objek/kejadian, aktivitas wawancara dengan nara sumber dan sebagainya. Kompetensi yang diharapkan paga kegiatan ini antara lain mengembangkan sikap teliti, jujur, sopan, menghargai pendapat orang lain, kemampuan berkomunikasi, menerapkan kemampuan mengumpulkan informasi melalui berbagai cara yang dipelajari, mengembangkan kebiasaan belajar dan belajar sepanjang hayat ${ }^{15}$.

d. Mencoba (experimenting)

Mencoba dimaksudkan untuk mengembangkan berbagai ranah tujuan belajar, seperti sikap, keterampilan, dan pengetahuan. Aktivitas pembelajaran lebih ditekankan kepada proses yang langsung dilakukan oleh siswa. Beberapa aktivitas yang dapat menggambarkan kegiatan mencoba ini adalah menentukan tema pembelajaran yang disesuaikan dengan kompetensi dasar yang dituntut dalam kurikulum, mempelajari bagaimana cara menggunaan suatu alat maupun bahan yang dipakai dalam suatu percobaan, mempelajari dan memperdalam dasar teori yang relevan dan hasil-hasil percobaan sebelumnya, melakukan dan mengamati percobaan secara teliti, mencatat fenomena yang terjadi kemudian menganalisisnya

\footnotetext{
14 Izzuddin, Ahmad. 2019. Efektivitas Pendekatan Saintifik Terhadap Kemampuan Berpikir Kritis Siswa dalam Pembelajaran IPA Kelas V MI NW Bagik Nyala. Jurnal Al-Muta aliyah : Jurnal Pendidikan Guru Madrasah Ibtidaiyah, 4(1), 141 - 165

15 Abdul Majid. (2014). Pembelajaran Tematik Terpadu. Bandung: PT Remaja Romiakarya
} 
dan disajikan dalam sebuah data, menarik kesimpulan atas hasil percobaan dan membuat laporan dan mengkomunikasikan hasil percobaan ${ }^{16}$.

Pengembangan keteranpilan yang diharapkan dari kegiatan mencoba ini adalah siswa diberikan ruang dan waktu untuk mengeksploitasi kemampuan diri yang masih belum dimaksimalkan oleh mereka. Melalui kegiatan ini juga sifat jujur dan teliri mereka akan diuji karena dalam melakukan suatu percobaan, mereka diharuskan melakukannya dengan penuh ketelitian.

e. Mengasosiasi (Associating)/ Mengolah Informasi, dan Menyimpulkan

Proses informasi yang sudah dikumpulkan melalui suatu eksperimen/percobaan maupun hasil dari kegiatan mengamati dan kegiatan mengumpulkan informasi diolah dengan memperhatikan keluasan dan kedalaman materi. Kegiatan ini dilakukan untuk mengidentifikasi keterkaitan satu informasi dengan informasi lainya. Kompetensi utama yang diharapkan adalah mengembangkan sikap jujur, teliti, disiplin, taat aturan, maupun kerja keras. ${ }^{17}$.

f. Mengkomunikasikan

Kemampuan berkomunikasi dengan baik sangat penting dimiliki oleh setiap siswa. Keterampilan berkomunikasi tidak hanya dilakukan secara lisan melainkan juga secara tertulis. Hal ini berkaitan dengan proses penyampaian informasi atau data-data ${ }^{18}$. Bentuk komunikasi yang baik adalah komunikasi yang dapat dipahami dan dimengerti degan mudah oleh penerima informasi. Kegiatan yang termasuk keterampilan berkomunikasi di antaranya menyajikan data dan informasi dalam bentuk lisan dan tulisan, menyajikan data dan informasi dalam bentuk model, gambar, grafik, diagram tabel, dan lain-lain ${ }^{19}$.

\section{Pembelajaran Daring}

\footnotetext{
${ }^{16}$ Kemendikbud. (2013). Draft Kurikulum 2013. Jakarta: Kemendikbud 17 . (2013). Peraturan Menteri Pendidikan dan Kebudayaan Nomor 65 tabun 2013 tentang Standar Proses Pendidikan Dasar dan Menengah. Jakarta: Kemendikbud

18 Stawa, K. R. 2020. Implementasi Pembelajaran dengan Pendekatan Saintifik (Scientific Approach) untuk Meningkatkan Hasil Belajar IPS Siswa Kelas VIII.A SMP Negeri 12 Mataram. BINTANG, 2(2), 336-352. https://doi.org/10.36088/bintang.v2i2.1057

${ }^{19}$ Usman Samatowa. (2011). Bagaimana Membelajarkan IP A di MI. Jakarta: Dirjen Dikti Depdiknas
} 
Munculnya Pembelajaran daring merupakan salah satu bentuk pola pembelajaran di era teknologi informasi seperti sekarang ini. Di samping itu pola pembelajaran ini sejalan dengan edaran pemerintah untuk menghindari peserta didik melakukan pembelajaran secara tatap muka di sekolah. Daring diterjemahkan dari pembelajaran online yang tersambung ke dalam jaringan internet. Pembelajaran daring artinya pembelajaran yang dilakukan secara online, menggunakan aplikasi pembelajaran maupun jejaring sosial. Materi pelajaran didistribusikan secara online begitupula dengan komunikasinya dan penilaiannya. Pembelajaran daring sendiri dapat dipahami sebagai pendidikan formal yang diselenggarakan oleh sekolah, yang mana peserta didik dan guru berada di lokasi terpisah sehingga memerlukan sistem telekomunikasi interkatif sebagai media penghubung keduanya ${ }^{20}$.

Pembelajaran daring atau yang lebih dikenal dengan nama online learning merupakan pembelajaran yang dilakukan dengan bantuan internet ataupun jaringan. Pembelajaran daring pada dasarnya adalah pembelajaran yang dilakukan secara teknologi yang tersedia. Meskipun demikian, pembelajaran daring harus tetap memperhatikan kompetensi yang akan diajarkan ${ }^{21}$. pembelajaran daring adalah bentuk pembelajaran yang mampu menjadikan siswa mandiri tidak bergantung pada orang lain. Pembelajaran daring merupakan suatu proses pembelajaran yang pemanfaatan jaringan internet ${ }^{22}$. Pemmbelajaran daring merupakan pelaksanaan pembelajaran yang dilakukan dalam jaringan agar mencakup target yang luas ${ }^{23}$. Pada umumnya pembelajaran daring memiliki tujuan memberikan layanan pembelajaran bermutu secara dalam jaringan yang bersifat terbuka untuk menjangkau target yang lebih banyak dan lebih luas.

Pembelajaran daring merupakan hal baru yang sebenarnya bisa dilakukan sejak lama. Akan tetapi, ketiadaan aturan yang jelas mengenai pelaksanaan pembelajaran ini membuat pembelajaran ini jarang atau hampir tidak pernah dilakukan. Untuk saat ini pembelajaran daring menjadi populer karena keadaan yang memaksa guru untuk berusaha beradaptasi dengan kebiasaan baru. Pembelajaran daring ini memiliki kelebihan

${ }^{20}$ A. N. B. R Sobron, Presepsi Siswa Dalam Studi Pengaruh Daring Learning Terhadap Minat Belajar, Pendidikan Islam Dan Multikulturalisme, 2019

21 Albitar S Syarifudin, Implementasi Pembelajaran Daring Untuk Meningkatkan Mutu Pendidikan Sebagai Dampak Diterapkan Social Distancing, Jurnal Pendidikan Babasa Dan Sastra Indonesia, 2020

22 Mhd Isman, Pembelajaran Media Dalam Jaringan (The Progressive And Fun Education Seminar, 2016)

${ }^{23}$ Yusuf Balfiqah, Esensi Pengembangan Pembelajaran Daring (Yogyakarta: Deepublish, 2015) 
dan kekurangan. Berikut beberapa kelebihan dan kekurangan dalam pembelajaran daring, antara lain:

1. Kelebihan belajar daring

a. Meningkatkan mutu pendidikan dengan memanfaatkan multimedia secara maksimal dan efektif dalam pembelajaran.

b. Menekan biaya penyelenggaraan pendidikan terutama pemanfaatan sumber daya dan teknologi yang semakin canggih.

c. Waktu yang digunakan lebih fleksibel karena menggunakan pembelajaran daring, guru dapat menentukan waktu untuk belajar dan juga pelajar dapat belajar sesuai dengan kemampuan masing-masing.

2. Kekurangan belajar daring

a. Tidak semua siswa dibekali dengan milik pribadi. Banyak dari mereka yang masih memakai perangkat milik orang tuanya untuk pembelajaran daring. Sedangkan kesibukan orang tua yang bekerja dapat mengakibatkan siswa tidak dapat mengikuti pembelajaran daring.

b. Metode pembelajaran daring yang bersifat monoton sehingga siswa kurang berinteraksi baik dengan guru maupun siswa yang lain, Hal ini juga membuat guru kesulitan mengontrol siswanya.

c. Tingkat pemahaman siswa berbeda-beda. Hal ini bergantung pada kemampuan individual siswa sehingga membuat ada beberapa siswa yang yang lambat memahami materi yang diberikan.

d. Kurangnya pengawasan orang tua saatmelakukan pembelajaran daring kadang membuat siswa kehilangan fokus.

\section{Pandemi Covid-19}

1. Virus Corona Covid-19

Infeksi corona virus merupakan penyakit yang disebabkan oleh virus corona dengan gejala utamanya berupa gangguan pernapasan. Penyakit ini muncul pertama 
kali pada akhir tahun 2019 di Wuhan, China. Karena lokasi munculnya di Wuhan, membuat corona virus juga dikenal dengan sebutan Wuhan virus.

Corona virus disebabkan oleh virus single stranded RNA yang berasal dari kelompok Corona viridae. Virus ini dinamakan corona karena permukaan virus ini berbentuk seperti mahkota. Virus ini masuk kedalam kelompok yang serupa dengan virus yang menyebabkan gejala yang sama dengan Middle East Respiratory Syndrome (MERS-CoV) dan Severe Acute Respiratory Syndrome (SARS-CoV) yang terjadi beberapa tahun sebelumnya. Walaupun virus ini serupa dengan virus lainnya, akan tetapi mutase dan daya penyebarannya yang sangat tinggi dan cepat membuat virus corona dari Wuhan ini dikategorikan virus baru karena belum pernah teridentifikasi pada manusia sebelumnya. Karena itu, virus ini juga disebut sebagai 2019 Novel Corona virus atau 2019-nCoV.

Gejala Corona virus bervariasi, mulai dari flu biasa hingga gangguan pernapasan berat menyerupai pneumonia. Gejala Corona yang umum dialami oleh orang yang terpapar virus ini antar lain:

a. Demam tinggi disertai menggigil

b. Batuk kering

c. Pilek

d. Hidung berair dan bersin-bersin

e. Nyeri tenggorokan

f. Sesak napas

Gejala virus corona tersebut dapat bertambah parah secara cepat dan menyebabkan gagal napas hingga kematian. Centers for Disease Control and Prevention (CDC) mengemukakan bahwa gejala infeksi virus corona 2019 dapat muncul mulai dua hari hingga 14 hari setelah terpapar virus tersebut. Namun, adanya ledakan jumlah kasus di Wuhan, China menunjukkan bahwa corona virus dapat ditularkan antar manusia. Virus ini bisa ditularkan lewat droplet, yaitu partikel air yang berukuran sangat kecil dan biasanya keluar saat batuk atau bersin. Apabila droplet tersebut terhirup atau mengenai lapisan kornea mata seseorang, maka orang 
tersebut berisiko untuk tertular penyakit ini. Semua orang dapat terinfeksi virus corona, akan tetapi ada kalangan masyarakat yang lebih rentan tertular virus ini, mereka adalah orang yang lanjut usia (lansia), memiliki penyakit kronis, dan memiliki daya tahan tubuh rendah.

Jadi, cara terbaik untuk menghindari penyakit infeksi corona virus adalah melakukan tindakan pencegahan secara aktif. Pencegahan yang dilakukan harus menjadi prioritas, CDC menyarankan setiap orang melakukan tindakan seperti rutin mencuci tangan menggunakan sabun pada air mengalir setidaknya selama 20 detik, Apabila air dan sabun tidak tersedia, bersihkan tangan menggunakan pembersih tangan berbahan alkohol (hand sanitaizer), hindari menyentuh hidung, mata, atau mulut terutama bila tangan masih kotor, serta kontak dengan orang yang sedang sakit., usahakan tetap di rumah bila sedang sakit, apabila bersin atau batuk tutup mulut dengan tisu atau dengan menekuk siku, sebisa mungkin untuk menghindari kontak dengan hewan ternak secara langsung, akan lebih baik jika tidak berpergian terutama ke daerah dengan kasus infeksi corona virus.

2. Dampak pandemi Covid-19 pada Proses Pembelajaran

Dunia Pendidikan saat ini sedang mengalami perubahan yang sangat besar. Pembelajaran tatap muka yang sebelumnya dilaksanakan 100 persen di sekolah, secara tiba-tiba mengalami perubahan yang sangat drastis. Sementara diketahui bahwa pelajar dan mahasiswa lebih banyak yang berasal dari masyarakat berpenghasilan rendah

Akibat dari pandemi covid-19 ini, menyebabkan diterapkannya berbagai kebijakan untuk memutus mata rantai penyebaran virus covid-19 di Indonesia. Berbagai upaya telah dilakukan oleh pemerintah Indonesia. Salah satu yang langsung berdampak pada masyarakat adalah pembatasan kegiatan sosial dengan melakukan physical distancing. Kegiatan ini mengharuskan masyarakat untuk menjaga jarak dan menjauhi kegiatan yang mengundang massa yang banyak seperti kerumunan, perkumpulan, dan menghindari adanya pertemuan yang melibatkan banyak orang. Tujuan penerapan physical distancing tidak lain untuk memutus rantai penyebaran pandemi covid-19 yang terjadi saat ini. 
Pemerintah juga menerapkan kebijakan yaitu Work From Home (WFH). Kebijakan ini merupakan upaya yang diterapkan kepada masyarakat agar dapat menyelesaikan segala pekerjaan di rumah. Pendidikan di Indonesia tidak luput dari kebijakan yang diterapkan. Bekerja ataupun belajar dari rumah menjadi keharusan untuk menyelamatkan dunia Pendidikan sebagai dampak dari pandemi covid-19. Kementerian Pendidikan Indonesia juga mengeluarkan kebijakan yaitu dengan meliburkan sekolah dan mengganti proses kegiatan belajar mengajar menggunakan sistem dalam jaringan (daring).

Permasalahan bary akan mencul dengan adanya system pembelajaran daring ini. Pembelajaran online isering terkendala oleh sinyal dalam mendapatkan informasi, sehingga menyebabkan siswa lambat mengakses informasi. Siswa terkadang tertinggal mendapat nformasi, sehingga mengakibatkan mereka terlambat dalam mengumpulkan suatu tugas yang diberikan oleh guru.

Penerapan pembelajaran online juga membuat pendidik berpikir keras menenukan model dan metode pembelajaran yang akan digunakan. Awalnya guru sudah mempersiapkan model pembelajaran yang selama ini digunakan, kemudian harus mengubah model pembelajaran tersebut. Penggunaan teknologi dalam menyelesaikan tugas pada siswa, disatu sisi menimbulkan kreativitas siswa dalam mengembangkan pengetahuan yang telah mereka miliki, akan tetapi disisi lainnya banyak hal yang masih menjadi pertanyaan bagi mereka, khusnya mengenai bagaimana pembelajaran daring ini berjalan dengan efektif. Seharusnya pandemic covid-19 tidak dijadikan kambing hitam dalam menyiapkan dan merencanakan pembelajaran yang baik. Guru dituntut untuk mampu menciptakan suatu produk pembelajaran kreatif dan menarik sehingga siswa dapat mengembangkan pemikiran melalui analisis mereka sendiri, tanpa keluar dari pokok bahasan materi yang telah disampaikan oleh guru.

Pembelajaran yang dilakukan dari rumah, seharunya dapat membuat orang tua lebih mudah mengawasi perkembangan belajar anak.. Orang tua lebih semestinya lebih mudah dalam membimbing dan mengawasi belajar anak di rumah. Pembelajaran yang dilakukan dirumah dengan bimbingan orang tua langsung akan menimbulkan komunikasi yang lebih intensif, sehingg hubungan kedekatan antara 
anak dan orang tuanya akan lebih erat. Orang tua dapat membimbing anak secara langsung mengenai materi pembelajaran yang belum dimengerti. Karena orang tua adalah institusi pertama dalam pendidikan anak, maka beban tanggung jawab yang selama ini dilimpahkan ke guru dapat dibagi dengan orang tua. Dalam kegiatan pembelajaran secara online orang tua dapat memantau sejauh mana kompetensi dan kemampuan anaknya. Kemudian ketidakjelasan dari materi yang diberikan oleh guru, membuat komunikasi antara orang tua dengan anak semakin terjalin dengan baik. Orang tua dapat membantu kesulitan materi yang dihadapi anak.

\section{Implementasi Pendekatan Saintifik pada Pembelajaran Daring}

Tahapan ini adalah bagian yang menggambarkan kegiatan yang dilaksanakan dalam mengimplementasikan pendekatan saintifik pada pembelajaran daring di Lembaga Pendidikan Dasar. Langkah-langkah pendekatan saintifik 5M (mengamati, menanya, mencoba, menalar dan mengomunikasikan) sepenuhnya tetap dapat dilaksanakan dalam pembelajaran tatap muka maupun pembelajaran daring pada masa pandemi Covid-19, hanya saja terlihat kurang maksimal karena tidak menggunakan media yang variatif dan guru terlihat dominan dalam mengajukan pertanyaan-pertanyaan terkait materi. Selain itu, dalam pelaksanaan pembelajaran daring siswa hanya diberikan tugas mengerjakan soal-soal evaluasi dan hanya sesekali praktik, dan guru pun tidak tahu apa siswa benarbenar paham atau tidak. Namun, pembelajaran yang menyenangkan dan tetap mendorong antusias peserta didik dalam proses ilmiah/pendekatan saintifik tetap terlihat. Selama pembelajaran daring, bimbingan belajar dilakukan oleh orang tua dengan tetap berkomunikasi dengan guru.

Lima langkah pendekatan saintifik terkadang membuat siswa mengalami sedikit kesulitan. Siswa Sekolah Dasar/Madrasah Ibtidaiyah ada yang masih kesulitan untuk mengikuti tahap menanya dan menalar pada pendekatan saintifik, bahkan ada diantara mereka yang memiliki kesulitan dalam berbahasa/berkomunikasi. Sedangkan pada tahap mengamati dan mencoba mereka bisa mengikuti dengan baik walaupun dalam pelaksanaan belajarnya tetap dengan bimbingan kedua orang tuanya. Pada tahap mengomunikasikan, selama siswa belajar di rumah mereka dapat mengikuti kegiatan 
pembelajaran karena kegiatan belajar dilakukan secara individu dengan pendampingan dan bimbingan dilakukan oleh orang tua.

Pembelajaran daring yang menerapkan pendekatan saintifik memiliki beberapa kelebihan yang dapat diamati antara lain:

1. Siswa tidak bergantung dengan guru. Jika biasanya di sekolah siswa selalu mengandalkan guru untuk bertanya tentang hal yang tidak ia ketahui, maka dengan pembelajaran daring siswa dapat belajar atau bertanya kepada orang tua maupun melakukan browsing di internet. Kegiatan menanya itu sendiri merupakan salah satu langkah penting dalam pembelajaran menggunakan pendekatan saintifik.

2. Fleksibilitas waktu, tempat dan kecepatan pembelajaran. Dengan menggunakan Elearning, pengajar dapat menentukan waktu untuk belajar dimanapun. Artinya kegiatan seperti mengamati maupun mencoba dapat dilakukan dimana saja tentunya dengan bimbingan orang tua maupun guru. Kegiatan mengamati dapat langsung dilakukan dengan cara berinteraksi langsung dengan lingkungan sekitar, begitupun dengan kegiatan mencoba. Kedua langkah pada pendekatan saintifik itu dapat dilakukan bersamaan maupun secara terpisah tergantung kemampuan yang dimiliki oleh anak.

3. Kegiatan menalar dan mengkomunikasikan dapat dilakukan oleh anak disaat mereka selesai melakukan percobaan sederhana. Hasil percobaan yang mereka lakukan dapat dikomunikasikan dengan bahasa mereka sendiri. Artinya bahasa yang digunakan dipahami oleh mereka namun akan disempurnakan oleh orang tua maupun guru sebagai pembimbingnya.

Selain beberapa kelebihan dalam pelaksanaan belajar daring, adapula kelemahan yang ditemukan antara lain:

1. Sinyal/koneksi. Sinyal/koneksi ini adalah faktor terpenting dalam pembelajaran daring, jika tidak ada sinyal/koneksi maka siswa terkendala dalam melakukan langkah-langkah pendekatan saintifik seperti mengkomunikasikan maupun mengirim kembali hasil yang diperoleh siswa dalam melakukan percobaan sedrhana.

2. Guru tidak dapat berintraksi secara langsung. Saat pelaksanaan pembelajaran daring, guru tidak mengetahui perkembangan siswa secara nyata. Pelaksanaan 5M (mengamati, menanya, mencoba, menalar dan mengomunikasikan) tidak sepenuhnya 
dalam bimbingan guru. Sehingga guru tidak mengetahui dengan jelas apakah siswa itu melakukan langkah-langkah tersebut.

3. Tidak semua siswa dibekali dengan milik pribadi. Banyak dari mereka yang masih memakai perangkat milik orang tuanya untuk pembelajaran daring. Sedangkan orang tuanya bekerja dari pagi hingga sore. Ini mengakibatkan siswa tidak dapat mengikuti pembelajaran daring.

4. Tingkat pemahaman yang berbeda-beda, tergantung kepada kemampuan siswa membuat ada saja yang tertinggal dalam memahami materi yang diberikan.

5. Kurangnya pengawasan orang tua dalam melakukan pembelajaran secara daring membuat siswa kadang kehilangan fokus.

\section{KESIMPULAN}

Pandemi Covid-19 telah berdampak besar dalam dunia pendidikan. Wabah ini telah banyak mengubah kebiasaan masyarakat utamanya dalam proses pembelajaran. Proses pembelajaran yang sebelumnya dilakukan dengan sistem tatap muka mulai perlahan tapi pasti diubah ke sistem pembelajaran lewat jaringan yang lebih dikenal dengan istilah pembelajaran daring. Dikarenakan system pembelajaran ini merupakan hal yang baru, maka berbagai kendala menyertai system baru ini. Pendidik dan peserta didik mencoba untuk beradaptasi lebih cepat supaya proses pembelajaran harus tetap dilaksanakan untuk menyelematkan generasi bangsa di tengah peningkatan dan kecepatan akses informasi melalui kemajuan teknologi. Proses pembelajaran yang menggunakan berbagai pendekatan salah satunya pendekatan saintifik harus selalu diterapkan meskipun berada pada masa pandemic covid-19.

Implementasi pendekatan saintifik selama pandemi covid-19 melalui pembelajarn daring di Lembaga Pendidikan Dasar sudah dilakukan dengan cukup baik. Pembelajaran daring dengan menggunakan pendekatan saintifik tidak hanya melibatkan guru dengan peserta didik saja akan tetapi orang tua peserta didik pun ikut ambil bagian dalam membimbing anaknya mengembangkan sikap ilmiah dan kritis anak tersebut. Kendala utama pembelajaran daring menggunakan pendekatan saintifik ini adalah masih terbatasnya sarana dan prasarana seperti kuota internet/paket data siswa. Lembaga 
Pendidikan mencoba mengatasi kendala tersebut dengan memberikan bantuan dari dana operasional sekolah maupun mencari kerja sama dengan pihak lain untuk kelancaran proses pembelajaran. Kendala-kendala lain baik yang bersifat teknis maupun kualitas pembelajaran akan terus disempurnakan oleh Lembaga Pendidikan.

\section{DAFTAR PUSTAKA}

Agus Sujarwanta. (2012). "Mengkondisikan Pembelajaran IPA dengan Pendekatan Saintifik”. Jurnal Nuansa Kependidikan Vol 16 Nomor.1, November 2012.

Albitar S Syarifudin, 2020. Implementasi Pembelajaran Daring Untuk Meningkatkan Mutu Pendidikan Sebagai Dampak Diterapkan Social Distancing, Jurnal Pendidikan Babasa Dan Sastra Indonesia,

Anhusadar L. O. 2020. "Kualifikasi Pendidik Sesuai Permendikbud Nomor 137”, Journal On Early Childhood Education Resears Joecher

Atsani L. G. M. Z., 2020. Transformasi Media Pembelajaran Pada Masa Pandemic Covid-19. Al-Hikmah: Jurnal Studi Islam

Basori B., 2017. Efektifitas Komunikasi Pembelajaran Online Dengan Menggunakan Media E-Learning Pada Perkuliahan Body Otomotif. Jurnal Ilmiah Pendidikan Teknik Dan Kejuruan, 2017.

Depdiknas, Permendiknas N0 22 Tahun 2006 Tentang Standar Isi (Jakarta: Depdiknas, 2006)

Hosnan \& Sihombang. (2014). Pengaruh Pendekatan Pembeljaran Matematika Realistik dan Saintifik terhadap Prestasi Belajar, Kemampuan Penalaran Matematis dan Minat Belajar. Jurnal Riset Pendidikan Matematika

Isman Mhd, 2016. Pembelajaran Media Dalam Jaringan (The Progressive And Fun Education Seminar, 2016)

Izzuddin, Ahmad. 2019. Efektivitas Pendekatan Saintifik Terhadap Kemampuan Berpikir Kritis Siswa dalam Pembelajaran IPA Kelas V MI NW Bagik Nyala. Jurnal Al-Muta aliyah : Jurnal Pendidikan Guru Madrasab Ibtidaiyah, 4(1), 141 $-165$

Kemendikbud. (2013). Draft Kurikulum 2013. Jakarta: Kemendikbud

Machin A., 2014. Implementasi Pendekatan Saintifik, Penanaman Karakter dan konservasi pada Pembelajaran Materi Pertumbuhan. Jurnal Pendidikan IPA Indonesia http://journal.unnes.ac.id/nju/index.php/jpii

Majid. (2014). Penggunaan Pendekatan Pembelajaran Saintifik dalam Menggunakan Hasil Belajar Matematika. Jurnal Ilmiah Mandala education

Majid A, 2014. Pembelajaran Tematik Terpadu. Bandung: PT Remaja Romiakarya

Musfiqon \& Nurdyansyah. (2015). Pendekatan Pembelajaran saintifik. Sidoarjo: Nizamia Learning Center. 
Nugraheni, A. S, Dan Hutami, M. S., 2020. "Metode Pembelajaran Melalui Whatsapp Group Sebagai Antisipasi Penyebaran Covid-19 Pada AUD, Pandia: Jurnal Penelitian Dalam Bidang Pendidikan Anak Usia Dini.

Pohan, A. E. (2020). Konsep Pembelajaran Daring Berbasis Pendekatan Ilmiah. Jawa Tengah: Sarnu Untung.

Samatowa U, 2011. Bagaimana Membelajarkan IPA. Jakarta: Dirjen Dikti Depdiknas.

Sobron A. N. B. R, 2019. Presepsi Siswa Dalam Studi Pengaruh Daring Learning Terhadap Minat Belajar, Pendidikan Islam Dan Multikulturalisme

Stawa, K. R. 2020. Implementasi Pembelajaran dengan Pendekatan Saintifik (Scientific Approach) untuk Meningkatkan Hasil Belajar IPS Siswa Kelas VIII.A SMP Negeri $12 \quad$ Mataram. BINTANG, 2(2), 336-352. https:// doi.org/10.36088/bintang.v2i2.1057

Sugiyono, 2010. Statistika untuk Penelitian. Bandung: Alfabeta

Sujarwanta, A. 2012. "Mengkondisikan Pembelajaran IPA dengan Pendekatan Saintifik". Jurnal Nuansa Kependidikan Vol 16 Nomor.1, November 2012

Supriyadi. 2008. Teknologi Pengajaran Fisika. Lombok Timur: Tempel Sari.

Suryosubroto, B. 2009. Proses Belajar Mengajar di Sekolah. Rineka Cipta. Jakarta.

Yusuf Balfiqah, 2015. Esensi Pengembangan Pembelajaran Daring. Yogyakarta: Deepublish (2013). Peraturan Menteri Pendidikan dan Kebudayaan Nomor 65 tahun 2013 tentang Standar Proses Pendidikan Dasar dan Menengah. Jakarta: Kemendikbud 